\title{
Питання психології
}

DOI: $10.33099 / 2617-6858-20-58-5-123-130$

Loboda Y. $\boldsymbol{O}$. candidate of philosophic sciences, associate professor, leading scientific fellow of National Defence University of Ukraine named after Ivan Cherniakhovskyi https://orcid.org/0000-0002-9121-6696

\section{ON THE CHALLENGES FOR STRATEGIC INTELLIGENCE: COGNITIVE BIASES AND INFORMATION OVERLOAD}

In the article on the basis of the contemporary Western literature were analyzed two main challenges for the analytical departments of strategic intelligence: cognitive biases and information overload. In the paragraph "Defining the core issue" it was stated that the problems of cognitive biases and informational overload are the permanent challenges, which have to be analyzed continuously. In the paragraph "Analysis of the latest publications" were pointed out the classic and contemporary works on psychology of intelligence and information overload. The main aim of the article is searching the ways of mitigating of negative consequences of the cognitive biases and information overload in strategic intelligence. In the paragraph "Exposition of the main material" were considered the typology of cognitive biases and essence of the information overload. In "Conclusions" were outlined possible ways of response to challenges of cognitive biases and information overload.

Key words: intelligence; cognitive bias; information overload.

Defining the core issue. The problems of cognitive biases in intelligence analysis and overcomplicating intelligence institutions in conditions of information overload are the classic issues for intelligence studies. They need to be reconsidered permanently according to historical changes.

Analysis of the latest publications. The following scholars focused their attention on the cognitive biases in intelligence analysis: $\mathrm{S}$. Marrin [9, 10], L.Johnson [15], R.J.Heuer [5], Moore [12]. The information overflow was analyzed (but not limited) by: C.E. Brueggemann [1], A. Oettinger [13], T.S. Thomas [16], K.J. Wheaton [17].

The aim of the article: to analyze essence of the contemporary challenges to intelligence analysis in the cases of cognitive biases and organizational consequences of information overload with ways of their mitigation.

Exposition of the main material. The question of influence of cognitive biases on the intelligence blunders is not free from biases itself: it is very easy to accuse members of intelligence community in cognitive biases when they fail (even if some other cause(s) actually worked out); the theoretical basis of the analysis of the cognitive biases is not unified: it contains diverse approaches taken from psychology and critical thinking theory, backed by formal logic.
Nevertheless, the notion of cognitive bias in intelligence analysis remains important for the studies in theory and history of intelligence.

Traditionally the cognitive biases are linked with human psychology. The weak sides of this approach are the following:

- Psychological biases are relevant only on the tactical and operational levels, where personal opinion (or group thinking) really matter. On the strategic level of intelligence analysis, where the role of a personality reduced, the task of search for the psychological roots of cognitive biases appears to be more complicated.

- Psychology deals with operations of analysis of motivation and description of cognitive biases, their logical structures and relation to norms which could help to avoid them remain obscured.

Nonetheless, the main advantage of the psychological approach, mainly represented by R.Heuer, is the following: the typology of the cognitive biases is profoundly described, the variety of its phenomena are classified: 'Biases in Evaluation of Evidence (The Vividness Criterion, Absence of Evidence, Oversensitivity to Consistency, Coping with Evidence of Uncertain Accuracy, Persistence of Impressions Based on Discredited Evidence); Biases in Perception of Cause and Effect (Bias in Favor of Causal Explanations, Bias Favoring Perception of 


\section{Питання психології}

Centralized Direction, Similarity of Cause and Effect, Internal vs. External Causes of Behavior, Overestimating Our Own Importance, Illusory Correlation); Biases in Estimating Probabilities (Availability Rule, Anchoring, Expression of Uncertainty, Assessing Probability of a Scenario, Base-Rate Fallacy); Hindsight Biases in Evaluation of Intelligence Reporting (Analysts normally overestimate the accuracy of their past judgments. Intelligence consumers normally underestimate how much they learned from intelligence reports. Overseers of intelligence production who conduct post-mortem analyses of an intelligence failure normally judge that events were more readily foreseeable than was in fact the case)' [5, pp. 111 - 173]. Another systematics based primarily on the psychological approach is the following: 'Evoked-Set Reasoning, Prematurely Formed Views, Presumption that Support for One Hypothesis Disconfirms Others, Inappropriate Analogies, Superficial Lessons From History, Presumption of Unitary Action by Organizations, Organizational Parochialism, Excessive Secrecy (Compartmentation), Ethnocentrism, Lack of Empathy, MirrorImaging, Ignorance, Rational-Actor Hypothesis, Denial of Rationality, Proportionality Bias, Willful Disregard of New Evidence, Image and Self-Image, Defensive Avoidance, Overconfidence in Subjective Estimates, Wishful Thinking (Pollyanna Complex), Best-Case Analysis, Conservatism in Probability Estimation, Worst-Case Analysis (Cassandra Complex)' [8, pp. 36-38; 4, pp. 106-107]. Dearth makes a very important notice: he writes about institutional causes of boosting the cognitive biases: "Biases can be enforced, or at least reenforced - formally or informally - by organizations through organizational parochialism and "group-think" and can have as their basis ethnocentrism. This phenomenon can operate at the level of given intelligence organizations, intelligence disciplines, or sectors of government. Some of these problems are rooted in the methodologies we select to analyze the world; but they all will certainly influence the way we use any given methodology. Consider, for instance, the problems associated with inappropriate analogies and superficial lessons from history. The latter invariably produces bad history and hence flawed understanding" [4, p.
105]. Thus, the task of mitigation of the cognitive biases belongs not to theoretical debates only; it relates to the organizational structures of intelligence community and the professionalism of its management.

Structured analytical techniques offered as one of the remedies of the cognitive biases faced their critics from the intelligence community: Stephen Marrin [10] argues that structured methods (at least in the time of his service in CIA in 1996-2000) are used very rarely; intelligence officers preferred intuition in their work. He states that structured techniques are perfect for making the process of analysis transparent and accountable (and therefore it would make analysis much more correct), but it takes more time to conform all the formalities related to this method. Overloaded officers usually work within the tight temporal frameworks, which makes using of structured techniques less preferable to them. Mitigating this problem may contain the following: to reduce exploitation of more problematic methods (like intuition) it would be possible to offer more convenient formal (structured) methods or/and special software to make their workflow more transparent and accountable, and as a result - more accessible for counter-bias inspections.

More fundamental approach is proposed by scholars who are based on the theory of critical thinking [12]. Being an applied form of traditional formal logic, critical thinking is focused not on the representations of cognitive biases, but on their structures and relation to the norms of correct thinking. Pitfalls related to the main elements of abstract thinking (notion (classification, comparison, definition, division), propositions (contradiction, controversy, negation), inference (induction, deduction, abduction, traduction) [12, p. 36], hypothesis and theories building, their falsification and verification, main laws of logic (identity, excluded middle, non-controversy, sufficient reason)) can be attributed not only to exact persons from IC, as it was in the case of the psychological approach, but to the pattern of the workflow of entire analytical groups and institutions. Logical tradition provides rigorous rules of the correct thinking which could help to avoid cognitive biases more effectively, than psychological approach proposes to do. 


\section{Питання психології}

The method of mitigation of the cognitive biases depends on the approach to them. Shallow, too generalized and wide prescriptions, given by representatives of the psychological approach [5, pp. 173 - 184] are not comparable with the approach of representatives of critical thinking scholars [12, pp. 95-96] - the last look way more fundamental and constructive, because refers not to exact personalities, but to universal cognitive structures, which can be detectable on the personal, group and institutional levels.

Developing critical thinking skills by intelligence analysts may allow to avoid not only personal errors, but institutional as well. This would conform the initial W.Platt's claim of the relevant education of the intelligence officers $[14$, p. 151, 284].

It is possible to choose between different strategies entailed by the choice between "Art" and "Science" (or any type of their combination), but intelligence officer is not required to overcome the limits of scientific methods which he uses. It is required knowledge about these limits, which will not guarantee any success, but can increase its chances. Problem of induction "Not to see a wood behind the trees" and Platonic-Hegelian maxim "If facts do not fit a theory, than it is worse for facts!" are archetypic, they are accessible by common sense, intuition or education. Mere verification will not help in all the cases; data (no matter how complete) does not provide its automatic understanding. In this case, intelligence becomes art, because understanding cannot be quantified and very specific training; thus, in this case the educational system bears full responsibility of developing of professional skills of intelligence officers.

There is no panacea against cognitive (and all the other) biases in intelligence analysis. Some scholars say that intelligence blunders are inevitable. But understanding of the inner limits of the scientific methods, the rules of correct thinking given by formal logic, rich tradition of semiotics, theory of Fregean "sense-meaning" distinction can create advantage for intelligence analyst at least over the enemy, which could not have these skills. Critical thinking should be used against myths, wrong mindsets, stereotypes, overand underrationalization of enemies and other cognitive biases by intelligence analysts educated in the most fundamental way - by training in logic and its applied form - critical thinking - can increase chances of avoiding the negative outcomes of cognitive biases.

Furthermore, any intelligence service could be easily blamed for incompleteness, fuzziness, obsoleteness of the information it provides, as well in errors in its analysis. The motto "the command's hunger for information is perpetual, you always have to deliver more information" was (or had to be) the fundamental principle of professional intelligence services - not only to avoid the accusations like that, but it has reflected the essence of intelligence work. This endless strife for perfection of fullness of information has been challenged by the recent technical development in informational domain, which caused overwhelming informational overflow for intelligence services, adding a new point of criticism against them. The data overload can make all the elements of processing of information less adequate; the organizational structures of intelligence agencies, channels of communication between participants of intelligence communities facing the urge of reforming.

The criticism against military intelligence was systematically articulated in "On war" by Carl von Clausewitz: "Many intelligence reports in war are contradictory; even more are false, and most are uncertain" [2, p. 117]. David Khan points out that it became usual to avoid the analysis of Clausewitz' view on intelligence [3, p. 125]. The rare academic criticism of Clausewitz's approach to intelligence, expressed by Ferris and Handel ("Clausewitz's views on operational intelligence were not simple, nor were they absolutely accurate, as shown by the experience of at least one contemporary. Devoting much personal attention to the task, the Duke of Wellington demonstrated that it was possible to collect useful tactical and operational intelligence on the enemy. A small but notable minority of British and American generals of that era adopted a similar view. From an examination of the same base of data as Clausewitz, the Baron de Jomini drew different conclusions about operational intelligence, and, over 2,000 years earlier, the influential Chinese strategist Sun Tzu praised - in fact, exaggerated - the military value of intelligence" [6, p. 3]) is followed by a statement, that makes Clausewitz's criticism more relevant 


\section{Питання психології}

to the issue of overcautiousness of a decision maker caused by the intelligence: "To Clausewitz, audacity is less dangerous in commanders than caution and less frequently found. 'Given the same amount of intelligence [in a commander], timidity will do a thousand times more damage in war than audacity'; 'a general cannot be too bold in his plans, provided that he is in full command of his senses, and only sets himself aims that he himself is convinced he can achieve'; 'We always have the choice between the most audacious and the most careful solution. Some people think that the art of war always advises the latter. That assumption is false. If the theory does advise anything, it is the nature of war to advise the most decisive, that is, the most audacious'; 'boldness grows less common in the higher ranks'; 'no case is more common than that of the officer whose energy declines as he rises in rank and fills positions that are beyond his abilities.' In Clausewitz's equation, uncertainty and its psychological consequences reduce the frequency of boldness among commanders and increase the value of this scarce commodity on the field of battle. If all commanders were aggressive risk-takers, this characteristic would define the military art but it would no longer offer a comparative advantage to any general. When most commanders are cautious, then audacity is at a premium" $[6, p .7]$. Contemporary strategists also follow Clausewitz in assessing the role of a commander, which faces the challenge of information overload, requiring rather professional preparation and psychological talents than optimization of information processing: "A complex-stable battlespace, for example, can result in information overload. A complexunstable environment generates an "overwhelming amount of information, but [decision makers] will not know which information to attend to due to constantly changing circumstances." To get a clearer picture of whether uncertainty breeds indecision or poor judgment among blue, red or other decision makers, this net assessment should be integrated with the psychological profiling of specific decision makers if possible. Some commanders and terrorist group leaders are capable of good judgment under uncertainty, but many are not." $[16$, p. $101-102]$.
The traditional problem of redundant cautiousness of commanders caused by intelligence is multiplied in our days by the technical revolution, which enormously increased the number of sources of information, made OSINT more crucial than ever before. In contemporary world, everyone drowns in the streams of information: "The information revolution has brought information overload. Everyone with a PC and an Internet connection runs the risk of being bombarded with ideas and images. While this can broaden an individual's perspective by providing access to different points of view and sources of information, it can also reinforce delusions by showing that others believe the same thing. Bizarre ideas and outright lies can be propagated much more easily than in the past." [11, p. 7-8]. New communication and computing technologies have offered optimization of data processing for intelligence services which significantly improved their capability: "Advances in scientific knowledge, translated into new technology, have made previously unmanageable intelligence tasks feasible and greatly increased the speed at which intelligence professionals perform traditional activities. Improved sensors, transmission capabilities, and analytical tools deliver unprecedented volumes of information and processing capabilities to the intelligence community and its customers, military and political decision makers. Processes that used to take days or weeks now take only seconds. Activities carried out at dispersed locations throughout the world can be managed centrally, ensuring coherence in the information delivered and a rapid flow of intelligence between the field and administrative office" [13]. Moreover, the emergence of the concept of "informational overload in intelligence community" happened before the "communication/computer" revolution and related to the organizational complexity: "Fundamental are the problems of overload and complexity. The very sophistication of modern information-gathering systems produces the problem of overload. Intelligence systems may demand ever more data in the empirical illusion that more data will solve the mysteries and secrets when, in fact, they are likely to suffer the fate of the thirsty individual who tries to drink from a firehose. As the 9/11 Report noted: "One 


\section{Питання психології}

can see how hard it is for the intelligence community to assemble enough of the puzzle pieces gathered by different agencies to make some sense of them. ... Accomplishing all this is especially difficult in a transnational case. We sympathize with the working-level officers, drowning in information and trying to decide what is important." Overload manifests itself also in the concept of "noise," wherein the glut of extraneous material inhibits the analyst from focusing on the information that is central to the analytical problem or even prevents the analyst from spotting it" [15, p. 154]. Thus, contemporary "informational overload" is a result of complexity of organizational structures and overwhelming streams of information, and therefore the ways of solving this problem does not relate to the improving procession of incoming data only - it is a systematic problem, which has to be analyzed within the frameworks of organizational reform as well.

The intelligence services are not excluded from the overloading with information, which has essential negative impact on the productivity of the analysts: "There is too much intelligence. A veritable flood comes in each day as message traffic, and then there is the vast amount of finished intelligence products available through government intranets. An analyst could easily spend all day doing nothing but reading intelligence and ton actually producing anything. But being an analyst, by definition, requires an effort to make sense of the pieces of the terrorist puzzle and provide value-added analysis" [7, p. 23]. Stephen Marrin writes about one of the ways of response to this challenge: "This overload of information could explain why CIA's analysts are organized in narrow accounts; because of the volume of information, issues must be segmented in order for a single analyst to master the relevant data. But it also has implications for the future. In order to ensure that analysts read all relevant information, the CIA may have to divide its workforce into smaller segments as more and more information becomes available" $[9$, p. 15]. Solving new problem with quantitative changes by increasing specialization in fragmented groups and potentially hiring more new specialists does not seem a final (or even satisfactory) solution.

Multiplying analytic groups complicates communication between groups and may increase internal informational overload with reports and other forms of accountability ("A network with a small number of critical nodes (mechanistic), for example, is more susceptible to disruption and information overload, while one that is highly decentralized is able to resist, adapt, re-route flows, and repair itself. On the other hand, communication and coordination are more difficult in spider webs. Generally, the organization will at least be a critical capability if not a COG itself. To get a sense of whether the organization is a strength or weakness, what its vulnerabilities are, and how it might be affected directly or indirectly, we need to assess its design, the independence of its units, the location of leadership, and "how hierarchical dynamics may be mixed with the network dynamics." (Thomas 2004, p. 159)), but this extensive response seems the most ineffective, although it remains the one of the main ways of responding the informational overload. It also contains the risks of complexing hierarchical interaction: bigger volumes of information could be required to be reduced and simplified, which can make the analysis more shallow [17, p. 10].

Charles E. Brueggeman proposes the following ways of mitigating the information overload:

- "Strong leadership must emerge from both business partners and IT specialists in order to solve the challenges of circular reporting and complexity of data sources. Both must reengineer their approach to resolving technology problems. As "end users" identify deficiencies that require a technology solution, IT specialists must partner with them by leveraging their expertise. The IT professional must draw out of the end user the scope of the deficiency, compliment that with their understanding of the domain, and facilitate the development and implementation of "context-based" technology tools." [1, p. $72-73]$. This approach requires flexibility of intelligence service, while some of which still remain conservative. The other problem is secrecy - civil IT contractors should be controlled, which requires extra resources and enlarges intelligence service structures. Own IT infrastructure developed within the intelligence service may suffer from isolation from the newest commercial market products and can get outdated rapidly; 


\section{Питання психології}

- "Awareness and focus: Establish within each fusion center a work team focused on circular reporting. This team should develop procedures and guidelines aimed at reducing circular reporting" $[1$, p. 74] - increasing internal reporting would boost informational overload and does not guarantee the optimization of the data processing. Contemporary world changes rapidly, the volume of information increases permanently, and the bureaucratic means of solution simply does not match the urgent requirements;

- "Best practices: Investigate successful models that are already addressing the broad issue of information overload and the specifics of circular reporting and complexity related to data sources" [1, p. 75] - the successful models in the globalized informational domain do not live long. They have to be changed simultaneously with the realities which they refer to. The well-developed bureaucratic machines of the intelligence communities are traditionally conservative and often do not show nor intention, neither ability to change;

- "Structure and operations: Explore and validate the relevancy of an intake, analyze, and disseminate model with other fusion centers. By engaging other centers and perhaps partnering with them, further advance the concept of a similar operational models that enable the sharing of information" [1, p. 77] - the analysis of relevance of incoming information is essential, but distinguishing this as a special procedure could take too much time, which is unacceptable during times of information overload. The relevance of information could be established during further systematic analysis and comparison with other data;

- "Survey of technologies: A more formal survey of duplicate detection as it relates to circular reporting in the intelligence and fusion center business should be undertaken. Finding a technology that would include artificial intelligence and learning algorithms that semantically analyzes the concepts of the document and possibly categorizes some into a domain taxonomy or ontology would be of great value. The ideal situation would be to mix and match these technologies, outfit the resulting tool with a user interface specifically designed for the intake function of a fusion center, and embed it in the work environment of the person performing the intake" $[1$, p. 78$]$ - this can work in the case when the outlined measures clearly showed their efficiency. Anyway, data processing will always require the personal involvement of a human with his/her experience, intuition, talents;

- "Training: An adaptable, automated, knowledge-driven, best practice and standard operating procedures technology must be developed and accessible to the analysts. It is through these automated standard operating procedures that technology will help drive the work of the analysts. Doing so will minimize the complexity of which data sources should or should not be utilized. Coupling this feature with automated federated access to data sources will further reduce the negative effects caused by the complexity of data sources" $[1$, p. 84-85] - higher intelligence officers recognize the current problem of adequate training of intelligence employees in the following way: 1 . The problem of gap between generations - young officers deal with the informational technologies way more effectively than their elder colleagues due to bigger interest to social networks, actual software, "natural OSINT skills" and merely bigger experience in that; 2 . The problem of versatility of educational background of the young employees - they are expected to have as versatile education as possible, because it is believed to improve their critical and creative capabilities. These can work only jointly with fundamental training in professional intelligence preparation, because the lack of this can destroy all the advantages of the up-to-date skills of young employees.

Conclusions. To summarize, it would be relevant to assert that:

- Intelligence services are often criticized primarily for incompleteness and obsoleteness of the information and analysis provided. From the other side, military decisionmakers often appear unready for the volume of information provided by intelligence; in this case, a better form of interaction between intelligence and command needed. Also more profound professional education in intelligence theory for staff officers and political leaders would help.

- The problem of information overloading of intelligence services is not entirely new - any relatively complex bureaucratic structure suffers from this, and intelligence community is not an 


\section{Питання психології}

exception; more resilient organizational structures are needed, which seems extremely hard to be done within conservative bureaucratic organizations;

- Organizational means of mitigating this problem simultaneously increases it - more analyst units and newly extra hired employees encourage internal paper/data exchange and help to plug up internal communication between members of intelligence community;

- Using modern electronic systems of data processing and communication for collecting, analyzing and disseminating intelligence is an enormous advantage. In the same time, the same tools create a uncontrolled stream of information which increases drastically and needs to be filtered, analyzed and assessed. This stream can be easily increased by a belligerent subject to guarantee the analysts' collapse - the capabilities of analyzing centers are limited, unlike the volume of incoming information, which can be potentially unlimited. In this case, some serious counter-overload measures should be taken: the specific techniques should be elaborated, which have to include the methods and tools of avoiding total collapse under the informational overload. Another problem related to this point is that belligerent actors use the common informational domain and technologies - this means that intellectual competition in this realm depends on the scientific success and as a result - on the technical superiority.

- Information overload forced intelligence analysts to revisit the role of OSINT, which enormously enlarged due to development of digital technologies. This should not change the understanding of HUMINT, which should remain fundamental. The informational skill can never substitute the talents required in HUMINT, but the informational overload can cause the shift of priorities of the members of intelligence communities in favor of SIGINT and OSINT.
- The technical tools of mitigating the information overload can not substitute the experience and intuition of humans. Therefore, along with technical development aimed to cope with information overload the biggest attention has to paid to development of human resources, because it is way harder to achieve. The extensive solution of increasing the quantity of employees to respond the information overload is not a ultimate remedy, but it would help better if the selection process of the incoming staff would be improved and bigger attention would be paid to their education, including science and programming training.

- Fulminantly changing world, which delivers drastically increasing volumes of information to be analyzed, requires adequate generation change. Contemporary intelligence services require young minds with their specific world wide web digital experience. This requires optimization and reconsidering of the transmitting of the professional skills and wisdom between generations. Mere informational exchange will not work, some personal involvement is needed. There is a threat that informational overload brings: not everything in the intelligence profession can be transferred from one generation of analysts to another, but the digital tools can create an illusion that previous experience is useless and everything can be solved only with computers.

- The problem of informational overload seems to be extremely hard to solve. The known measures taken mainly belong to extensive methods: hiring extra analysts and improving software and hardware of digital processing centers. Following the data opened to civilians it is hard to find any more successful method other than extensive ones. Decision makers are always hungry for information, but it is still a huge challenge for services not to drown in the ocean of information. The more effective solution is still to be found.

\section{References}

1. Brueggemann C.E. Mitigating Information Overload: The Impact of "Context-Based Approach" to the Design of Tools for Intelligence Analysts - Thesis, Naval Postgraduate School, Monterey, CA, 2008.

2. Clausewitz C. von. On War. - Princeton University Press, 1984.

3. David Kahn. Clausewitz and intelligence, The Journal of Strategic Studies, 1986, 9:2-3, 117-126.

4. Dearth D.H. Politics and Intelligence // Strategic Intelligence: Theory and Application. / Ed. by D.H.Dearth, R.T.Goodden. - Carlisle Barracks: United States Army War College, Center for Strategic Leadership; Washington, D.C.: Defense Intelligence Agency, Joint Military Intelligence Training Center, 1995. 


\section{Питання психології}

5. Heuer R.J., Jr. Psychology of Intelligence Analysis. Center for the Study of Intelligence, Central Intelligence Agency, 1999.

6. Ferris J., Handel M.I. Clausewitz, Intelligence, Uncertainty and the Art of Command in Military Operations // Intelligence and National Security, 1995, 10:1, 1-58.

7. Kauppi M. Counterterrorism Analysis 101. // Defense Intelligence Journal, 11, no. 1 (Winter 2002).

8. Krizan L. Intelligence Essentials for Everyone. - Washington, DC, Joint Military Intelligence College, 1999.

9. Marrin S. Intelligence Analysis: Structured Methods or Intuition? / American intelligence Journal, 2007.

10.Marrin S. Improving Intelligence Analysis: Bridging Gap between Scholarship and Practice. - Routledge, Taylor and Francis Group, 2012.

11.Metz S. Armed Conflict in the 21st Century: The Information Revolution and Post-Modern Warfare. Strategic Studies Institute, 2000. 2009.

12.Moore D.T. Critical Thinking and Intelligence Analysis. - Washington: National Defense Intelligence College,

13.Oettinger A. Information Overload: Managing Intelligence Technologies // http:/hir.harvard.edu/article/?a=1061

14.Platt W. (1957) Strategic Intelligence Production. Basic Principles. New York, Frederick A. Praeger, Publishers, 1957.

15.Strategic Intelligence. Vol. 1. / Ed. by L. Johnson. - Praeger Security International, 2007.

16.Thomas T.S. Beneath the Surface: Intelligence Preparation of the Battlespace for Counterterrorism. - Joint Military Intelligence College, 2004.

17.Wheaton K.J. The Warning Solution: Intelligent Analysis in the Age of Information Overload. - Fairfax, VA: AFCEA International Press, April 2001.

\section{ВИКЛИКИ СТРАТЕГІЧНОЇ РОЗВІДКИ: КОГНІТИВНІ АБЕРАЦЇ ТА ІНФОРМАЦІЙНЕ}

\section{ПЕРЕНАВАНТАЖЕННЯ}

У статті «Виклики стратегічної розвідки: когнітивні аберації та інформаційне перенавантаження» на основі огляду сучасної західної літератури проаналіовано два основних виклики, з якими стикаються аналітичні відділи стратегічної розвідки: когнітивні аберації та інформаиійне перенавантаження. Головна мета статті - пошук способів усунення негативних наслідків когнітивних абераиій та інформаиійного перенавантаження в стратегічній розвідиі. Зазначено, щзо проблеми когнітивних абераиій та інформаційного перенавантаження є постійними викликами, які треба досліджувати перманентно. Вказано на класичні та сучасні роботи з психології розвідки та дослідження з проблем інформаційного перенавантаження. У розділі Розглянуто типологію когнітивних аберачій та сутність інформаиійного перенавантаження в сучасних умовах. Окремо зазначено, що складність дослідження когнітивних аберацій в аналітичній роботі стратегічної розвідки полягає в тому, щро иі дослідження самі не є вільними від таких аберацій $і$ часто залежсать від академічної кон'юнктури або особистого досвіду дослідника - зокрема, традиційно проблематика когнітивних аберащй належить такій иарині мілітарних досліджень, як «Психологія розвідки», при цьому може ігноруватись логічні аспекти когнітивних помилок, які мають універсальний, а не особистісний характер. Розглянуто сутність феномену інформаційного перенавантаження, який стає дедалі помиренішим в умовах бурхливого розвитку електронних засобів комунікації, проаналізовано способи вирішення проблеми інформачійного перенавантаження, запропоновані Ч.Е.Брюггеманом.

У висновках приведені можливі способи відповіді на виклики когнітивних аберачий та інформащійного перенавантаження.

Ключові слова: розвідка; когнітивна абераџія; інформаційне перенавантаження.

Recelved/Поступила: 21.12. 20. 